\title{
O papel científico, social e político dos congressos: novos parâmetros para um futuro melhor
}

Uma série de artigos foi recentemente publicada sobre congressos que contribuíram para mudanças expressivas no mundo contemporâneo ${ }^{1-5}$. Esses eventos históricos foram raros, mas marcantes. Ora pela mudança óbvia na direção do conhecimento, ora pelos grandes acordos políticos fechados, que nortearam o futuro das áreas. Se é verdade que são raros, também é verdade que a maioria dos especialistas provavelmente concorda que raramente se espera ouvir grandes novidades em uma conferência. Essa afirmação nos remete à áspera pergunta: são - realmente - necessários os congressos?

O número crescente de congressos é motivo de preocupação. Obviamente, a velocidade da produção de conhecimento está aumentando, mas a multiplicação de congressos é, por vezes, mais explicada pelo prestígio conferido a uma instituição que sedia um evento, e pelo seu retorno financeiro, do que pelo desejo de proporcionar intercâmbio intelectual. Além disso, muitos encontros não deixam claro seus objetivos, e várias palestras não têm coesão entre si.

Todavia, é importante lembrar que as conferências científicas tradicionais possuem vários propósitos, e o grande trunfo desses acontecimentos é a força da interação e do estabelecimento de redes de relacionamento. $\mathrm{O}$ poder do contato olho no olho na geração de novas idéias, pensamentos e colaborações não pode ser subestimado, e a tecnologia não o superou. É nas apresentações em congressos que pesquisadores expressam suas opiniões de forma mais livre, descompromissados com o formato rígido dos artigos científicos.

A vida dinâmica e estressante da atualidade faz dos congressos uma pausa para mudança de ambiente e foco, propiciando um ambiente criativo para novas idéias científicas e comerciais. Também é uma pausa para atualização, que muitas vezes as pessoas não encontram em suas rotinas diárias. Além de, é claro, ser o momento de reencontrar amigos ligados entre si pela profissão. E o turismo associado às convenções é um negócio que movimenta grandes somas de dinheiro em todo o mundo.

Quando um encontro está em vias de ser concebido e se deseja, realmente, que seja relevante para os congressistas, algumas regras básicas devem ser seguidas. Primeiramente - e acima de tudo - os organizadores precisam ser claros em relação aos objetivos do evento. Isso significa mais que ter um tema que preencha um quesito burocrático. A comissão organizadora tem que se esforçar para que os palestrantes se atentem e adiram ao tema. Isso inclui inserir na grade de apresentadores apenas pessoas capazes de falar com grande expertise sobre "aquele" tema, mesmo que englobe assuntos de diferentes áreas.
Em segundo lugar, recursos de tecnologia devem ser implementados para aumentar a comunicação com a comunidade que frequentará o congresso. Malas diretas eletrônicas - não de propaganda convencional, mas com conteúdo informativo - devem ser enviadas. Adicionalmente, vídeos disponibilizados no YouTube podem ser espalhados por meio de links, para que todos possam entrar na atmosfera, tanto científica quanto social, dos dias que virão.

Também para otimizar o aprendizado, o número e a duração das apresentações formais devem ser enxutos, com poucas exposições orais de mais de uma hora de duração. Além disso, após a palestra, os apresentadores devem ficar à disposição da platéia para responder perguntas em local pré-definido, dispondo, se possível, de quadro e caneta e da própria apresentação em um monitor de computador. Esses encontros podem até ser realizados na área comercial do congresso, durante os, sempre importantes, intervalos para o café. Isso aumenta a interação com os professores.

Não se pode deixar de fora dos congressos as apresentações de pôsteres e temas livres. São nessas modalidades que as estrelas do futuro começam a despontar e o laboratório propiciado por essas exposições é indispensável para o crescimento profissional.

Por fim, e não menos importante, deve-se lembrar que a palavra congresso tem como raiz etimológica a conversação. Assim, é inclusive um momento para que pessoas de posições políticas e ideológicas distintas sentem à mesa para tratar dos interesses da área. Esses encontros não devem ser patrulhados ou cerceados, pois apenas, única e exclusivamente o conhecimento gera progresso e cria um futuro melhor.

Bons congressos!

Jorge Faber - Editor Chefe

\section{REFERÊNCIAS}

1. BERG, P. Meetings that changed the world: Asilomar 1975: DNA modification secured. Nature, London, v. 455, p. 290-291, 18 Sep. 2008.

2. DELISI, C. Meetings that changed the world: Santa Fe 1986: human genome baby-steps. Nature, London, v. 455, p. 876, 16 Oct. 2008.

3. HARDIN, L. S. Meetings that changed the world: Bellagio 1969: the green revolution. Nature, London, v. 455, p. 470 , 25 Sep. 2008.

4. HOUGHTON, J. Meetings that changed the world: Madrid 1995: diagnosing climate change. Nature, London, v. 455, p. 737, 8 Oct. 2008.

5. ROSE, F. Meetings that changed the world: Paris 1951: the birth of CERN. Nature, London, v. 455, p. 174-175, 11 Sep. 2008. 